\title{
Predictors of early sexual intercourse on middle adolescents in Medan
}

\author{
Rahmi Lubis ${ }^{1,2}$, Zahrotur Rusyda Hinduan ${ }^{1}$, Ratna Jatnika ${ }^{1}$, Hendriati Agustiani ${ }^{1}$ \\ ${ }^{1}$ Faculty of Psychology, Universitas Padjadjaran, Indonesia \\ ${ }^{2}$ Faculty of Psychology, Universitas Medan Area, Indonesia \\ Corresponding author: makmunrahmi@yahoo.com
}

\section{ARTICLE INFO}

Article history

Received December 13, 2020

Revised June 5, 2021

Accepted June 26, 2021

Keywords

adolescence;

early sexual intercourse;

ecological theory;

family;

personal characteristics;

environment.

\begin{abstract}
Early sexual intercourse causes negative consequences for adolescent health. Understanding sexual predictors can be beneficial for the prevention program. This study aims to describe predictors of early sexual intercourse among adolescents. The study participants were twenty sexually experienced respondents aged 15-18 years and received assistance from the Indonesian Family Planning Association (PKBI) in Medan. The study used a qualitative approach using semi-structured interviews as methods. The results show that individual, family, peer, school, and media influence early sexual intercourse. Individually, participants have unstable emotions, negative self-concepts, and unclear future orientation. They are also unable to make rational decisions, lack social responsibility, and often violate the rules. Therefore, sexually, the respondents have positive sexual attitudes, sexually active peers, and high sexual selfefficacy. Especially among male participants, the internet was used to meet sexual partners and watched sexually-laden videos. The participants also have dysfunctional families, friends with behavioral problems, and disengagement with school. Therefore, prevention programs need to strengthen adolescents' positive potential, family function, social support, and healthy media use.
\end{abstract}

\section{Introduction}

Healthy sexual behavior, which entails avoiding pregnancy and sexually transmitted infections, is one of the challenges adolescents face in their sexual development (Steinberg, 2002). However, changes in community life values cause adolescents to become sexually active at a younger age, including vaginal sexual behavior. Vaginal sex is a form of sexual behavior using male and female genitals (Benokraitis, 2011). A study in America found that $75 \%$ of 18 year-olds are sexually active (Halpern \& Haydon, 2012). Forty percent of teenagers are pregnant before 20, and 30\% of these pregnancies end in abortion (Heart, 2010). Meanwhile, 7.7\% in 2012 and 9\% Indonesian high school students engaged in sexual intercourse (Bauer, 2015; Sari \& Rokhanawati, 2018).

In Indonesia, parents rarely talk about sex because they consider it taboo (Wanufika, Sumarni, \& Ismail, 2017). This condition results from the Eastern cultural and religious values that reject premarital sexual intercourse (Wong, 2012). Society instills the concept of virginity to keep youths sexually abstain until the right time. Therefore, youngsters with 
the experience of premarital sexual intercourse would feel ashamed because of public punishment (O'Donnell, Utomo, \& McDonald, 2020). The community forbids sexual intercourse until the wedding day, making it difficult for teenagers to get contraceptives (Brooks-Gunn \& Paikot, 1993). However, this semi-restrictive attitude does not eliminate premarital sex from adolescent life. Eastern society still allows heterosexual interaction, which encourages teenagers to have sex secretly to avoid public punishment (Steinberg, 2002). Difficulty obtaining contraception drives them to have unprotected sex or preventing pregnancy in ineffective ways. BKKBN reported that teenage pregnancy rates reached $4.8 \%$ of adolescents aged 10 to 24 years (Utami \& Nodia, 2016).

As the third-largest city in Indonesia, Medan is the center of the education, economic, and entertainment activities in North Sumatra (OECD/ADB, 2015). Many migrants go to Medan for school and employment (Bennett, 2005). Many village youths come to Medan to continue their education, and they need to cover the lack of monthly expenses from their parent. A survey has shown that 50 senior high school students in Medan stated that 30 to 60 of their school friends are involved in prostitution (Detik News, 2007). Other surveys found 52\%of adolescents (Joewono, 2010) and 40\% of middle school students (Ginting, 2016) had had vaginal sex.

Sexual intercourse at an early age is risky sexual behavior because it was done without an adequate understanding of sexual intercourse risks, with multiple partners and without contraception (Kaplan, Jones, Olson, \& Yunzal-Butler, 2013). Also, it might increase the risk of unwanted pregnancy, sexually transmitted diseases, and reproductive disorders (Young, Burke, \& NicGabhainn, 2018). At the same time, pregnancy and sexually transmitted infections will cause psychological distress for adolescents (Haase, Landberg, Schmidt, Lüdke, \& Silbereisen, 2012). In turn, increasingly intense sexual activity and the emergence of other risky behaviors then cause psychological effects and mental disorders such as depression, anxiety, and suicide (Steinberg, 2002).

The ecological theory stated by Small \& Luster explains three-level factors that influence adolescents' sexual behavior: individual level, familial level, and extra-familial level, with individual factors, are the most important (Steinberg, 2002). Individual factors such as physical conditions (Akers et al., 2016; Landor \& Halpern, 2016) and psychological conditions (Peltzer \& Pengpid, 2016) were associated with sexual risk behavior. The second factor is family factors, including parental monitoring, parentadolescent relationship quality, parental support, and parental sexual expectation affecting adolescent sex behavior (L. Somers, 2011; Okigbo, Kabiru, Mumah, Mojola, \& Beguy, 2015; Sychareun et al., 2013). Furthermore, Kao \& Manczak (2013) added that good family functioning is a key factor in reducing teen sexual intercourse. The third factor is extra familial factors, including peers, school environment, and neighborhood. Adolescents will imitate peer behavior and norms (Epstein, Bailey, Manhart, Hill, \& Hawkins, 2014; Hussen, Bowleg, Sangaramoorthy, \& Malebranche, 2012; Potard, Courtois, \& Rusch, 2008). School enrollment (Santelli et al., 2015) and media (Chen, Neilands, Chan, \& Lightfoot, 2016) also contribute to sexual experience.

Studies that explore the individual, familial, and extra-familial factors on teenagers' sexual behavior in Medan are limited. Therefore, this study will explore what factors predict early sexual intercourse among adolescents in Medan. The research questions are: What factors influence the sexual behavior of adolescents aged 15 to 18 in Medan based on ecological theory? How do individual, family, peer, school, and environmental factors contribute to adolescents' early sexual behavior of adolescents aged 15 to 18 in Medan? 


\section{Method}

This research is descriptive qualitative research with a phenomenological approach, aiming to describe the phenomenon from the subject's point of view. The Research Ethics Committee of Padjadjaran University reviewed and approved the study protocol with number 0519030473.

\section{Participants}

Using criterion-based sampling, we recruited subjects aged 15 to 18 years who were sexually active and participants in the reproduction health program of PKBI in Medan. The participants were twenty adolescents 15 to 18 years ( 11 females, nine males), who came from low social, economic levels and most of them live separately from parents and school dropped out (Table 1). Researchers obtained participants through PKBI key persons who arranged the schedule and location for data collection according to the participant's request. The researcher interviewed participants one by one based on the key person's reference until the researcher concludes that the data obtained is sufficient and reaches a saturation point with twenty participants.

Table 1

Demographic Characteristic of Respondents

\begin{tabular}{|c|c|c|c|c|c|c|c|}
\hline No & Name & Sex & Age & Education & Parents & Job & Residence \\
\hline 1 & $\mathrm{~A}$ & $\mathrm{~F}$ & 17 & Grade 11 & Divorce & Waitress & Rental \\
\hline 2 & B & $\mathrm{F}$ & 17 & High school & Married & Unemployed & Boarding house \\
\hline 3 & $\mathrm{C}$ & M & 16 & Grade 5 & Divorce & Day laborer & Parent's \\
\hline 4 & $\mathrm{D}$ & $\mathrm{F}$ & 17 & Junior High & Divorce & Waitress & Boarding house \\
\hline 5 & $\mathrm{E}$ & M & 17 & Primary & Married & Driver & Parent's \\
\hline 6 & $\mathrm{~F}$ & $\mathrm{~F}$ & 17 & Grade 9 & Step family & Waitress & Dormitory \\
\hline 7 & $\mathrm{G}$ & M & 17 & Grade 5 & Married & Parker & Parent's \\
\hline 8 & $\mathrm{H}$ & M & 17 & Grade 10 & Single mom & Parker & Parent's \\
\hline 9 & I & $\mathrm{F}$ & 17 & Grade 10 & Married & Waitress & Dormitory \\
\hline 10 & $\mathrm{~J}$ & M & 18 & Senior High & Divorce & Day laborer & Parent's \\
\hline 11 & K & M & 18 & Grade 8 & Married & Waitress & Dormitory \\
\hline 12 & $\mathrm{~L}$ & $\mathrm{~F}$ & 18 & Grade 11 & Divorce & Waitress & Dormitory \\
\hline 13 & M & $\mathrm{F}$ & 18 & Senior High & Married & Waitress & Parent's \\
\hline 14 & $\mathrm{~N}$ & M & 17 & Grade 6 & Divorce & Day laborer & Parent's \\
\hline 15 & $\mathrm{O}$ & M & 17 & Grade 7 & Step family & Waiter & Rental house \\
\hline 16 & $\mathrm{P}$ & $\mathrm{F}$ & 17 & Junior High & Married & Waitress & Boarding house \\
\hline 17 & Q & M & 18 & Grade 8 & Step family & Keyboard player & Parent's \\
\hline 18 & $\mathrm{R}$ & $\mathrm{F}$ & 17 & Grade 9 & Divorce & Waitress & Dormitory \\
\hline 19 & S & $\mathrm{F}$ & 18 & Grade 7 & Step family & Waitress & Dormitory \\
\hline 20 & $\mathrm{~T}$ & M & 18 & Grade 6 & Married & Parker & Dormitory \\
\hline
\end{tabular}

\section{Procedures}

The researcher asked permission from the director of PKBI to recruit the respondents. The respondent signed the informed consent before the researcher conducted a personal semistructured interview, with an interview guidelines based on the context of adolescent development, namely individual, family, peer, school, and leisure time (Steinberg, 2002). Experiences during development stages from early childhood to adolescence, family backgrounds such as relationships with parents and siblings, relationships with peers, experiences at school and teachers, relationships with the surrounding community, daily 
activities including sexual activity, hobbies, gadgets, and future orientation were asked in the interview that was recorded with the subject's permission. The informed consent and the respondent's identity were stored carefully and separately to keep the subject's identity confidential. The completion of the data were checked before the data analysis process.

\section{Data analysis}

The audio recording was transcribed and organized chronologically into verbatim. Data analysis by coding and identifying the conclusion, theme, and category (Poerwandari, 2007). The researcher looked at the common thread of the scattered data through the intrapersonal and interpersonal levels. The credibility, transferability, and dependability of research results were achieved. Data suited each another, information consistent at different times, and the subject approved the conclusions made by the researchers.

\section{Results}

A content analysis produced five main themes, individual, family, peer, school, and media, from the interview results. The explanation of each theme is as follows.

\section{Individual}

Low emotional competence. The subjects often lose their temper and show an aversive response to others. They could not express their negative emotions correctly and tended to be aggressive, which caused interpersonal conflict with others.

The subjects cannot express and regulate their emotions effectively. "I get emotional easily, especially if provoked (by someone) to be angry" (M). They react aggressively to dissent or interpersonal conflict. "It is because of friends teasing me. When I got emotional, I beat my friend. I sulk a lot for no reason. My friends don't know what pissed me off" (I).

Low social competence. Negative perceptions of authority figures make them reluctant to fulfill responsibilities. They cannot understand other people's perspectives and do not respect the interests of others.

They find it difficult to adapt to the school environment. "I did not like the teacher. So I did not take the national exam. I left and went home" (B). They show less responsible behavior towards others. "I never keep a promise. I said one hour, but I came later than one hour" (E). They also manipulate others to gain peer acceptance. "I was often asked to collect money from friends from other classes ... if I refuse, they don't want to be friends with me. The money is bought snacks to eat together" (G). They oppose and ignore parental advice. "I always fighting with parents and ignoring their advice" (D).

Low moral competence. The subjects experienced many pressures in their life such as unfavorable economic conditions, broken families, and unsatisfactory social relations. A lack of support makes it challenging to develop patience and acceptance of reality, so they run away from problems and take shortcuts. The subject even chooses to do the wrong actions according to the teachings of their religion. The subjects also violate the rules at home or school environments so that they get punishment.

The subject commits an act that violates the laws and rules of society "The neighbors already know that I am like, evil, a thief" (T). The subjects consider sexual intercourse unnatural before marriage because it is contrary to social and religious norms. "I realized I had the sin to do things that parents forbid" (D). However, they considered that the 
prohibition of having sex was no longer suitable for today's lifestyle "I was afraid to get pregnant. But now people say there's already sex protection. It is okay, that's normal, people say $(P)$.

The subjects often disobeyed the parental rules about interacting with the opposite sex and night activities. "If I go out at night, I should go home at nine or half-past ten. Leave the house from eight o'clock. Sometimes I get annoyed with my parents, so I leave quietly. I'll be back at half-past eleven. When I got home, I got scolded" (I). They quietly meet with the boyfriend/girlfriend and lie to hide their faults. "Yes, my mom believes me as long as I left the house wearing a school uniform. But actually, I went with my man" (Ae).

Low decision-making skills. The conflict between authorities' values and their peers' influence makes it difficult for them to make rational decisions, so they tend to follow what peers do. They are also not trained at home to perform systematic decision-making steps before taking action. The subjects cannot assess the consequences of their actions to only fixated on immediate pleasure. Low decision-making skill causes them to regret their actions, such as skipping school, committing violence, or having sexual intercourse.

The subjects tend to conform to peer pressure to do bad things. "She said, you want lots of money? Do you want to work? What kind of work? Never mind. Tonight, you wait for me in front of your house. Okay, I will be waiting in front of the house. Get dressed. So I did it" (D). The subjects do not think carefully so that they make wrong decisions. "I regret doing it (sexual intercourse). Hey, I have destroyed everything" (Ae). The subjects committed the wrong action and regretted it "Because I was guilty. I sold everything at home, gas cylinders, Honda, father's work equipment, to buy crystal meth. I feel guilty. It was the result of hanging out with those friends" $(\mathrm{T})$.

Negative self-concept. The subjects judge themselves to be ugly and worthless in the eyes of others. They considered other people as disregarded their existence and capabilities. Subjects feel that they are not accepted by others, causing inferiority, social detachment, and self-pity.

The subjects have a negative self-concept, low self-regard, and high self-blaming. "Among those people, I'm just the most stubborn" (I). The subjects feel disregarded and rejected by friends. "People have always underestimated me. They come to me only when I am happy. When I was sick, no one cares about me except my parents." (S).

Unclear Future Orientation. The subjects do not have a clear long-term life goal. They do not have a robust value system that directs the ideals. They only focus on short-term goals like survival and having a family.

The subjects did not have a clear plan for their future. "Just to work and earn some money, Ma'am" (D). The subjects dream of a better life without knowing how to get it. "Well, I want to change, ma'am. I want to change my life. Yes, I just want to be somebody, ma'am. I don't know how to do it. The important thing is I just want to save money." (N). They even feel hopeless about having a good life. "I want to make my parents happy, but I cannot" (I).

High sexual self-efficacy. The subject had a partner who was sexually experienced. Sex partners coerce, persuade, and direct the subject to have sex. Male subjects also learned how to have sex from sex videos on the internet. Sexual intercourse occurs in private and 
accessible places such as an empty house, dormitory, hotel, or home when parents sleep at night. Subjects agreed to have sex while being sexually aroused. Information from the internet and friends makes them believe they can prevent the negative consequences of sexual intercourse, such as pregnancy or sexual diseases. Their sexual knowledge, pressure from their partners, and a promoting environment make them capable of having sexual intercourse.

The subjects have sex when sexual desire arises, and parents are not at home. "Yes, it is. She is what, so sexy. Yes, when I went to her house, she just finished taking a shower, walked into her room wearing only a towel. It is just a fad, right? And there is no one at the house" (G). The subjects even had sexual intercourse at their partner's house when the parents had fallen asleep at night. "Indeed, I am already close to her family. I did sleep there that night. I asked to sleep there. At first, I slept with her brother. We have different rooms. When her brother came out, her mother slept, so it happened." (K). The sexual partner also forced them to do sexual intercourse. "I did not dare. Like I said before, my girlfriend forced me. She insisted and asked me to go to the hotel. What are we going to do there, I said? Just follow me, she replied. I followed her. Yes, it happened then" (E).

The subject felt that he was able to overcome the negative consequences of sexual intercourse. "Yes. I heard stories from friends. They said that if you don't ejaculate inside, then she's not pregnant." (K). Subjects believe they can prevent pregnancy or sexually transmitted diseases depends on the way they do. "Because she's clean. Not having sex with other men. It's just me. So I won't have any (sexually transmitted) diseases" (O).

Positive sexual attitudes. The subject realizes that extramarital sexual intercourse risks pregnancy and sexually transmitted diseases and is against religious and social norms. However, sex can meet basic needs that they cannot get from their parents. They get money to eat, shelter, buy clothes from sex. Sex partners also provide attention, affection, protection, and emotional attachment. Subjects can also channel sex drive and gain sexual satisfaction. The subjects tend to see sexual intercourse as beneficial, giving rise to a great intention.

Female subjects considered sex as a way to make money. "So, it is not enough if I only hold ten thousand rupiahs for a week. So, I sleep with him (to get some money)" (R). Sex also makes the subjects get attention and protection from partners. "Yes. I feel loved by him when we have sex" (D).

Sex is an expression of love and a way of showing affection to a partner. "I have sex with him because I love him. I want to make him happy" (M). Sex is also a way to satisfy sexual urges. "I did not think of doing it before, Ma'am. It is just when I meet her, it just happened" (D). Subject has sex to maintain her romantic relationship with her boyfriend." Yes. He also said if I did not want to do it, then he did not want me. Understand?" (M).

\section{Family}

Harmony. The conflict between parents creates guilty feelings and discomfort at home. Poor financial conditions and bad parental habits are the sources of conflict. Parental divorce made subjects feel sad, angry, and disappointed. Disharmony with siblings due to parental favoritism also makes the subject feel uncomfortable at home. Subjects feel lost and lonely at home so that they go outside with friends.

The subject often witnessed quarreling of their parents or quarrel with siblings. "Parents often disagree. He often calls his female pedicab passenger. Mama pouted. He said my father was cheating, so they clash. Every day they were fighting. The father said 
he was just a regular passenger. They talk out loud and curse each other, ma'am. Sometimes they throw stones at the people in the house."(Ea). Parents' arguing is caused by jealousy or financial problems. "Father did not give mom money for household needs, so mom got angry. Dad doesn't have money, so they fought. Dad hit mom, and then mom cried. Angry with each other, then mom asked for a divorce" $(\mathrm{O})$.

The source of conflict also comes from a parent's bad habits, such as gambling and drinking. "My father used to be drunk a lot. Often play gambling. That's why my mother left my father" (L). Family conflict makes them feel uncomfortable at home. "I ran away from home, many times" $(P)$.

Mutuality. Family conflict situations prevent subjects from having emotional attachments with family members. Parental second marriage or the presence of stepparents made the subject feel rejected, unloved, do not get support and attention from their family.

Parental separation causes them to lose affection. "Imagine we were small, but mama rented a separate house for us. Sometimes she delivers our food, sometimes not. Mama told us to eat at grandma's place. Because of that, I thought that her attention was only for a moment to us. But she wants her children to pay attention to her. Sometimes she says, you guys, why do you ignore me. Even though mom also ignores her children" (Ea).

The subject felt that the family members were distant and did not think about the other. "No. We don't care for each other. There's no brotherhood either. That's why we if there is a problem, we rarely talk about it." (O) The parents' second parental marriage makes parents tend to prioritize their new family. "She is busy with her new husband" (Ea). They feel bored and lonely at home. "No friends at home. I would rather hang out with friends outside" (D). The presence of stepparents also creates feelings of abandonment. "We know what a mother is, but a stepmother is different. Her feeling of love is also different. My pocket money has also decreased" (Q).

Parental behavior problem. Parent's bad habits, such as drinking, gambling, or cheating, become the sources of conflict in the family. These bad habits also encourage parents to maltreat the subjects that cause them to feel uncomfortable at home.

Subjects have parents who have behavioral problems. "Drink alcohol too. Dad likes to drink it. After work, he drinks in the canteen or at a tuak (fermented palm wine) shop. He was with girls and mom was the one who often picks him up" (T).

Parent-adolescent relationship. Ineffective communication arises from parents' attitudes, which tend to blame and punish the subject for wrong actions harshly. The subject felt rejected and kept their distance from their parents even more. Parents often engage in verbal, physical, and psychological violence, making the subject even more hostile and showing resistance to their parents. Parents treat subjects differently from other siblings, which creates sibling rivalry worsening their relationship with the parents.

Subjects have conflicting relationships with their parents. "Why do you rarely come home? I am reluctant to see mom. We don't get along" (B). The subject felt hostility and rejection from their parents. "I do not know what my fault is. My neighbor called me an outcast" (P). Parents hate the subjects and maltreat them so that they feel miserable. "Sometimes, when I don't do my work, mom said that I was always burdening her. He said so. It broke my heart" (B). 
The subjects feel parents do not understand them and tend to impose their will on them. "I wanted to be free and quit school because my parents always didn't let me leave the house" (I). Parents cannot speak clearly, and the subjects feel confused about how to respond to it. "He told me to pick my uncle up somewhere. I just remained silent because it is not clear where to go. Then, he said to me, this animal did not move from its seat. So, I turned the TV off, and I cussed at him right away" $(K)$.

Parental control. Parents inadequately controlled subject behavior by verbal and physical punishment. Incongruent discipline between parents and inconsistent controls make the subject confused and disobeying the rules. The night activities outside make it difficult for parents to control the environment's influence on the subject. This discrepancy in parental monitoring makes subjects more quickly involved in risky sexual behavior.

Parents give physical punishment. "Mom beat me up, using a belt, or a rattan stick, or a broom" (D). Parents speak harshly. "My mom said, If you go out of this house, you do not need to go back and forth. Indeed, I did not come home one day" (R).

Parents do not adequately supervise the subjects. "That's because I'm not allowed to leave. You become dissidents if you are too restrained" (R). The parents are in disagreement on the way they treat their children. "When mom wants to beat me, dad blocked her. He said, don't get mad when your daughter comes home, so she doesn't want to come home again. Dad said to me to turn on my cellphone if I don't go home and I can take a becak If I can't find any vehicles" (P). Some parents are indifferent, so the subjects are free to go outside all night. "I was playing around until late at night. When I am in grade 8, I already know the outside world. That's where daddy began to change" (D).

Parental concern. Parents were unable to meet family needs because of their poor financial condition that worsen because of gambling and consuming drugs habit. Parental separation also made the subject feel abandoned because parents no longer pay for their children's living costs and makes them experience various inconvenient situations.

The parents do not provide adequate protection and care to their children. "Mom told us to ask for food at Grandma's house" (G). The parental bad financial condition drives the subjects to make their own money to live. "Dad did not have money to pay for it, Ma'am, my exam fees. That is why my father sent me to Perawang for work" (L). Parental separation caused the subject to have to live in another family house and receive unpleasant treatment. "I live separately from my mother because she has to work. I live in my aunt's house. If we live with extended family, we will be tormented. When I was a kid, I lived with my aunt, and it felt like everything was lacking. I did all the housework, cleaning, tidying up. I rarely go to school because they don't regularly wake me from sleep. I feel hurt. Just because of a little mistake, the results are harrowing. The child is naughty, but I am the one who gets punished" (R).

\section{Peers}

Peer pressure. The sexual values and behavior of peers became a standard of sexual behavior among the subject. The subjects believe that peers support and engage in sexual intercourse. Their friends informed them about how to have sexual intercourse, pushed and even mocked them when the subject claimed to have never had sexual intercourse.

The subjects have an undermining partner, teasing, even lying to make them willing to have sex. "If you do not give me your virginity, I will play with other girls, he said" (B). 
The subjects get sexual information from peers who teach them how to have sex. "I used to be innocent. My friends taught me, so I just went along like that. They said, just do ngengek (ngengek = have sex). Ngengek is good. Do it, come on. I don't know anything. I'm like a hypnotized person. I just shut up. I was silent, but I did it. Hehe. (I). The friend encouraged them to have sex and mocked them when the subjects refused to have sex. "It's a pity that you never get rations (sexual intercourse) from your guy" (I).

Peer sexual experience. Their friends share their sexual experiences with the subjects through chatting or sending their sex videos. He looked it up on the internet" (A). Some of the subjects have a sexually experienced partner.

The subjects have seen peers having sex and even joined with friends when doing so. "Me, with my girl and him, with the girl. We, slept in one room. So we did it" (O). The friends told the subject that they had had sex. "This friend of mine, she is loyal. She is different from other friends who always change partners, like a sugar daddy, young kids, or college student or anyone" (I). Their friend made a video recording of him having sex and sent it to the subject. "Yes, sex videos. He's having sex. Someone's recording it. Recorded using a cellphone when he has sex. Then he sent it to me" (E).

Peer behavioral problems. Subjects have peers or partners who engage in risky behaviors, such as smokers, school dropouts, run away from home, had sexual intercourse with multiple partners and have a gambling and drugs addiction. "Smoking, gambling, yes. He always misbehaved. Drug abused. And he ran away from home" (D).

\section{School}

Poor school adjustment. The subjects were disengaged from the school environment. Family problems decreased concentration and motivation to learn. Parental divorce also disrupted the subject's daily activities, including getting up early and attending school. Subjects become uninterested in studying, skip classes, and do not do homework to have low academic achievement. They find other fun activities when they skip school, so they are less motivated to attend class. Economic difficulties also make them have to drop out of school.

They do not engage with the subject and miss the lesson up. "I am sad because my mother and father separated. My report card grades went down. Sometimes I attend school, and sometimes I don't. I did my homework, sometimes at home, sometimes at school. Skipping classes often" (Ea). They are demotivated and have poor academic achievement, so they escape by breaking school rules. "I never do homework, always come late to school, I never study at school. When I was told to open a book, I never do it. I sleep. I don't care. The important thing is going up to the next class. That's all." (A).

The subjects did not focus on the lesson because of finding enjoyable activities while skipping classes or being addicted to substances. "At my state elementary school, I skipped lessons to watch TV and smoke at Grandma Ngatemi's house" (O). The subjects experienced financial difficulties so that he could not pay tuition fees and was expelled from school. "I was given a letter from the school. They said I got dropped out because I hadn't paid tuition. Grandma said it was natural because we couldn't afford to pay the school fees. I don't want to quit school. But what else can I do? Grandma is getting old. There's no way I keep asking for money from my grandmother" (L). 
Poor relationship with the teacher. The inability to understand lessons and fulfill financial obligations to the school invites a negative response from teachers. Teachers who often embarrass subjects in front of friends make subjects even more reluctant to go to school as they feel uncomfortable. The teacher's poor treatment of the subjects causes discomfort while in class. It encourages them to avoid attending class. "The teacher told me to answer the questions on the board, but I did not understand. the teacher scolded me, so I went out" $(\mathrm{K})$.

Poor relationship with school friends. The school friends have often bullied them because of their academic performance or physical appearance. Even conflicts with friends cause the subject to engage in violence, so they get expelled from school. The subjects find it difficult to adjust with school friends. "I am not serious about studying. I just wanted to be playful while my friends were different. Yes, because I was emotionally unstable while they were serious, like adults. They don't get along with me. Maybe I was in the wrong situation there too. When they study, I annoy them to make everyone laugh. But they didn't respond" (K). The subject's school friends sometimes insult the subjects because of the work they do or because of their physical appearance. "When break time comes, a commotion usually occurs. Hey, look at that, there is an ugly creature in the canteen, they said to me" (K). The subjects were expelled from school because they committed severe fighting with their friends. "He beat me on the head. I fight him back. The school kicked me out after hitting him with a piece of the board" (Ae). "I frowned and cut his cheeks till it bled, so they kicked me out of school" (K).

\section{Media}

Social media use. Subjects make games as a fun alternative activity to replace school learning activities. They make friends on social media, including getting their sexual partners from it.

The subject has a game addiction, so he no longer wants to go to school. "Sometimes friends told me, let's not go to school. Just go to the internet cafe, play games. I'm already game addicted. Yes. My game addiction made me lazy to study" (Q). The subject knew his first sex partner through social media. "I did it for the first time with a girl I knew from Facebook. Get to know her from Facebook. She provoked me first. The chats are so hot" $(N)$.

Sexual media exposure. The male subjects also find much sexual information from videos on the internet by watching them regularly. The male subject also shared sexually charged messages with friends.

Some friends taught them to watch pornographic videos. "Because of the video sent by my friend. I saw it once, so I am curious about how it feels. In my opinion, it is not a big deal" (Er). "Watching sex videos for the first time in grade 1 junior high school. I watched it when my friend showed it to me. I was invited to watch from an internet café. Now I watch it from my cellular phone once a week" $(O)$.

\section{Discussion}

The results showed that individual, family, peers, school, and media factors influence the respondents' early sexual intercourse. For the individual-level indicators, findings emphasize that the subjects show a low emotional awareness and regulation. They act 
aggressively and get into conflict with those around them. Low-stress tolerance makes subjects reactive to others' actions and finds it difficult to cope with the stress, so they vent it by having sex. Lando-King et al. (2015) posit that low intrapersonal skills, interpersonal skills, and stress management correlated with risky sexual behavior in adolescents.

The conflicts with parents, siblings, and peers create a negative self-concept. Lack of self-confidence breeds hostility towards others, so they find it hard to build satisfying social relationships with others. Low self-confidence also causes feelings of pessimism about the future and does not have ideals. The subject feels unable to achieve positive things and focuses on finding comfort in peer relationships. This emotional attachment encourages teens to conform to peer sexual pressure to have sexual intercourse. Shek \& Leung (2016) stated that having a negative self-concept, unclear plans, and low social competence correlated with high sexual behavior in adolescents. Besides, they cannot determine their behavior independently and think deeply about the consequences of their actions. They follow the lifestyle of their peers even though it is against the values taught by their parents (Ng et al., 2015).

The economic condition coupled with limited education and employability provides a finite choice of subjects for work. It makes them tend to see sexual intercourse as beneficial and give rise to a great intention (Sneed, Tan, \& Meyer, 2015). Sexual partners support the subjects financially and provide attention, protection, and acceptance, which their families cannot afford.

Living apart from parents and ineffective parental supervision gave the subjects the freedom to engage in sexual activity. Sexual information from friends, sexual experiences, and intense interactions with partners foster self sexual efficacy and opportunities for sexual intercourse. Palacios (2019) stated that higher sexual self-efficacy causes a higher intention to have sex.

The subject comes from dysfunctional families with intense conflict and hostility between family members, poor communication, lack of needs fulfillment, and inadequate parental control. Somers \& Anagurthi (2014) mentioned that low family function correlated with adolescent sexual behavior. Parental divorce and family economic difficulties resulted in several difficult situations, such as living abandoned, maltreatment from other families, and dropping out of school. This negative life situation encourages adolescents to engage in early sexual intercourse (Cheney et al., 2015).

Poor treatment from parents makes adolescents reluctant to meet parental expectations and focus more on obtaining their own needs. Leung \& Lin (2019) posit that weak bonding and low prosocial involvement pose a greater risk for sexual intercourse. The subject views parents as not a source of affection as expected. Parent's neglect of the subject's feelings and rude ways of communicating encourage them to find comfort and acceptance from their sexual partners. Okigbo et al. (2015) state that poor parentadolescent communication accelerates adolescence for first-time sex. Lack of parental supervision of youth activities outside provides opportunities to take actions contrary to parental values. Ineffective parental control allows the subject to engage in sexual intercourse sooner than they should (Dittus et al., 2015).

Peers are a significant reference in adolescence so that they constantly compare themselves with friends and try to comply with peer value standards. Peer sexual pressure encourages adolescents to engage in sexual intercourse (Van de Bongardt, Reitz, Sandfort, \& Deković, 2015). Perceptions of peers' sexual behavior affect adolescent sexual behavior (Chen et al., 2016). The subjects also agreed to have sex with their partners because they 
wanted to please and not disappoint them. Adolescents have sex to avoid hurting feelings and satisfy partners (Suleiman \& Deardorff, 2015). Subjects also have peers or partners who engage in risky behaviors that will increase the tendency for risky sexual behavior (Wang, Stanton, Deveaux, Li, \& Lunn, 2015).

Findings show that the inability to meet academic demands at school creates inferiority feelings, and it is hard to concentrate on studying, in line with Hensel \& Sorge (2014) statement. Teachers' poor treatment and schoolmate's bullying lead to truant behavior and violence to others. As a result, the school then expelled the subject for violating school rules. No longer in school pose a risk for engaging more in sexual activity than teenagers who go to school (Santelli et al., 2015).

The frequent use of the internet increases the chance of being exposed to sexual information (Chen et al., 2016). Spectacles in videos or sexual images obtained from friends cause the urge to have sexual intercourse. Temple \& Choi (2014) and Ybarra, Strasburger, \& Mitchell (2014) explained that texting habits lead them to be more sexually active. The use of the internet and social media also allows the subject to get to know friends who have the sexual experience to become their sexual partners.

The three levels of factors that influence adolescent sexual intentions interact with one another (Lyness \& Fischer, 2019). Parental treatment shapes the subject's personality become low social and moral ability, negative self-concept, low decision-making skills, and low future orientation. Furthermore, parents gave harsh punishment based on their misconduct behavior. Conflict within the family and feelings of anger and disappointment with parents create psychological pressure and an urge to bond with peers. Peers socialize values that support sexual behavior as a way out to meet both physical and psychological needs. Subjects conform to their sexual partner, who acts as a source of livelihood, affection, and happiness.

Lack of support and parental educational aspirations resulting a difficulty adapting to the school environment. Furthermore, teachers and friends give punishment for their unexpected actions. Therefore, subjects react emotionally in conflicts with teachers and friends, which resulted in being expelled from school. Quitting school exacerbates conflict with parents and an increasingly poor view of themself. Disappointment and guilt pull subjects into peer groups that provide comfort and experience the same failures. Dropping out of school causes them to lose their routine and have much free time, which increases the chance of engaging in sexual activity. This condition is strengthened by media present sexual partners and sexual knowledge, which increases their sexual self-efficacy.

Inefficient personality, weak family function, negative peer influence, problems at school, and negative media influence, encourage adolescents to have early sexual intercourse. Reciprocally, adolescent sexual activity worsens feelings of self, increases conflict with parents, increases dependence on peers, increases the desire to leave school, and uses sexual media more intensely.

Despite its contribution to offering adolescents and school counselors to help youth with sexual behavior problems or develop early sexual intercourse prevention programs, this study has several limitations. First, the generalization of this study results into adolescents in other cities in Indonesia. The subjects of this study are adolescents who receive reproductive health services from North Sumatra PKBI, reside in Medan, and have a low socioeconomic level. Hence, further research needs to seek whether this phenomenon also applies to subjects with different socio demographic backgrounds. The male and female subjects are different in financial reasons for having sex and watching pornographic videos so that further research needs to consider gender variables. 


\section{Conclusion}

Individual, family, peer, school, and media play a role in adolescents' early sexual intercourse. Adolescents who have weak personal characteristics, are raised in an improperly functioning family, have a low school engagement, have sexually active friends, and are exposed to media containing sex, tend to engage in sexual intercourse earlier. A holistic perspective is needed in understanding adolescent sexual behavior problems. Individual characteristics are profound risk factors for early sexual intercourse. Environmental factors, not only the influence of peers but family function, academic selfesteem, school engagement, and media, also contribute to increased sexual risk. The continued sexual information from the media needs to be balanced by parents without taboo views about sex. Parents need to carry out sexual communication in a comprehensive and dialogical manner. Therefore, adolescents build capacity for healthy and appropriate sexual decisions considering their physical and mental well-being. Sexual communication will be successful if parents build relationships with adolescents based on openness, trust, mutual respect, and understanding. The parents' ability to develop a harmonious family, caring for each other, warm relationships, meeting children's needs, and supervising adequately, will encourage adolescents to accept and internalize parental values properly. Involving peers and using media for healthy sex campaigns will be beneficial for adolescents. In addition, the school needs to create a positive and healthy school atmosphere with good cooperation between school management, teachers, and students will drive the adolescents to feel comfortable and involved in school activities.

\section{References}

Akers, A. Y., Cohen, E. D., Marshal, M. P., Roebuck, G., Yu, L., \& Hipwell, A. E. (2016). Objective and perceived weight: Associations with risky adolescent sexual behavior. Perspectives on Sexual and Reproductive Health, 48(3), 129-137. https://doi.org/10.1363/48e11416

Bauer, S. (2015). The association of sociodemographic, behavioural and informational factors with engaging in sexual intercourse among never-married adolescents aged 15 - 24 years in Indonesia: A secondary analysis of DHS data from 2012. Unpublished Dissertation. Retrieved from https://urn.kb.se/resolve?urn=urn:nbn:se:uu:diva-254694

Bennett, L. R. (2005). Women, Islam and modernity: Single women, sexuality and reproductive health in contemporary Indonesia. The Routledge Curzon.

Benokraitis, N. V. (2011). Marriages and families: Changes, choices, and constraints. Pearson Education Incorporation.

Brooks-Gunn, S., \& Paikot, L. (1993). Sex is a gamble, kissing is a game. Adolescent sexuality and health promotion. In S. S. Millstein, A. Peterson, \& E. Nightingale (Ed.). Promoting the health of adolescents: New directions for the twenty first century (pp. 180-2008). Oxford University Press.

Chen, A. C., Neilands, T. B., Chan, S. M., \& Lightfoot, M. (2016). Contextual influence of Taiwanese adolescents' sexual attitudes and behavioral intent. Nursing \& Health Sciences, 18(3), 355-361. https://doi.org/10.1111/nhs.12278

Cheney, M. K., Oman, R. F., Vesely, S. K., Aspy, C. B., Tolma, E. L., \& John, R. (2015). Prospective association between negative life events and initiation of sexual intercourse: The influence of family structure and family income. American Journal of Public Health, 105(3), 598-604. https://doi.org/10.2105/AJPH.2014.302311 
Detik News. (2007). Hasil penelitian: Ratusan pelajar Medan terjuni bisnis seks (Research results: Hundreds of Medan students are in sex business). News Detik.Com. Retrieved from https://news.detik.com/berita/d-863943/hasil-penelitian-ratusan-pelajar-medanterjuni-bisnis-seks

Dittus, P. J., Michael, S. L., Becasen, J. S., Gloppen, K. M., McCarthy, K., \& GuilamoRamos, V. (2015). Parental monitoring and its associations with adolescent sexual risk behavior: A meta-analysis. Pediatrics, 136(6), e1578-e1599. https://doi.org/10.1542/peds.2015-0305

Epstein, M., Bailey, J. A., Manhart, L. E., Hill, K. G., \& Hawkins, J. D. (2014). Sexual risk behavior in young adulthood: Broadening the scope beyond early sexual initiation. Journal of Sex Research, 51(6), 721-730. https://doi.org/10.1080/00224499.2013.849652

Ginting, J. (2016, February 6). Survey tunjukkan 40 persen remaja di Medan lakukan seks praniah (The survey shows that 40 percent of teenagers in Medan do premarital sex). Tribunnews.Com. Retrieved from https://www.tribunnews.com/regional/2016/02/06/survei-tunjukkan-40-persenremaja-di-medan-lakukan-seks-pra-nikah

Haase, C. M., Landberg, M., Schmidt, C., Lüdke, K., \& Silbereisen, R. K. (2012). The later, the better? Early, average, and late timing of sexual experiences in adolescence and psychosocial adjustment in young adulthood. European Psychologist, 17(3), 199212. https://doi.org/10.1027/1016-9040/a000082

Halpern, C. T., \& Haydon, A. A. (2012). Sexual timetables for oral-genital, vaginal, and anal intercourse: Sociodemographic comparisons in a nationally representative sample of adolescents. American Journal of Public Health, 102(6), 1221-1228. https://doi.org/10.2105/AJPH.2011.300394

Heart. (2010). Lets talk about sex education: A guide to effective programming for muslim youth. Retrieved from https://hearttogrow.org/wpcontent/uploads/2020/07/HEART_Guide_sexed_programming-1.pdf

Hensel, D. J., \& Sorge, B. H. (2014). Adolescent women's daily academic behaviors, sexual behaviors, and sexually related emotions. Journal of Adolescent Health, 55(6), 845-847. https://doi.org/10.1016/j.jadohealth.2014.07.008

Hussen, S. A., Bowleg, L., Sangaramoorthy, T., \& Malebranche, D. J. (2012). Parents, peers and pornography: The influence of formative sexual scripts on adult HIV sexual risk behaviour among Black men in the USA. Culture, Health \& Sexuality, 14(8), 863-877. https://doi.org/10.1080/13691058.2012.703327

Joewono, B. N. (2010, December 28). Seks bebas 51 persen abg tak perawan. (Free sex, 51 percent of Teengers are not virgins). Kompas.Com. Retrieved from https://entertainment.kompas.com/read/2010/12/28/17394533/seks.bebas.51.persen.ab g.tak.perawan

Kao, T. S., \& Manczak, M. (2013). Family influences on adolescents' birth control and condom use, likelihood of sexually transmitted infections. The Journal of School Nursing, 29(1), 61-70. https://doi.org/10.1177/1059840512444134

Kaplan, D. L., Jones, E. J., Olson, E. C., \& Yunzal-Butler, C. B. (2013). Early age of first sex and health risk in an urban adolescent population. The Journal of School Health, 83(5), 350-356. https://doi.org/10.1111/josh.12038

L. Somers, C. (2011). The role of parents in early adolescent sexual risk-taking behavior. The Open Psychology Journal, 4, 88-95. https://doi.org/10.2174/1874350101104010088 
Lando-King, E., McRee, A. L., Gower, A. L., Shlafer, R. J., McMorris, B. J., Pettingell, S., \& Sieving, R. E. (2015). Relationships between social-emotional intelligence and sexual risk behaviors in adolescent girls. Journal of Sex Research, 52(7), 835-840. https://doi.org/10.1080/00224499/2014.976782

Landor, A. M., \& Halpern, C. T. (2016). The enduring significance of skin tone: Linking skin tone, attitudes toward marriage and cohabitation, and sexual behavior. Journal of Youth and Adolescence, 45(5), 986-1002. https://doi.org/10.1007/s10964-016-0456-8

Leung, H., \& Lin, L. (2019). Adolescent sexual risk behavior in Hong Kong: Prevalence, protective factors, and sex education programs. The Journal of Adolescent Health, 64(6S), S52-S58. https://doi.org/10.1016/j.jadohealth.2018.12.007

Lyness, K. P., \& Fischer, J. L. (2019). Gender, sexual identity, and families: The personal is political. Michigan Publishing https://dx.doi.org/10.3998/groves.9453087.0005.001

Ng, J. Y., Wong, M. L., Chan, R. K., Sen, P., Chio, M. T., \& Koh, D. (2015). Gender differences in factors associated with anal intercourse among heterosexual adolescents in Singapore. AIDS Education and Prevention, 27(4), 373-385. https://doi.org/10.1521/aeap.2015.27.4.373

O'Donnell, J., Utomo, I. D., \& McDonald, P. (2020). Premarital sex and pregnancy in Greater Jakarta. Genus, 76(1), 1-22. https://doi.org/10.1186/s41118-020-00081-8

OECD/ADB. (2015). Education in Indonesia: Rising to the challenge, reviews of national policies for education. OECD Publishing. https://doi.org/10.1787/9789264230750-en

Okigbo, C. C., Kabiru, C. W., Mumah, J. N., Mojola, S. A., \& Beguy, D. (2015). Influence of parental factors on adolescents' transition to first sexual intercourse in Nairobi, Kenya: A longitudinal study. Reproductive Health, 12, 73. https://doi.org/10.1186/s12978-015-0069-9

Palacios, J. (2019). Predictors of personality and self-efficacy of sexual risk behavior in Mexican adolescents. Anales de Psicologia, 35(1), 131-139. https://doi.org/10.6018/analesps.35.1.319471

Peltzer, K., \& Pengpid, S. (2016). Risk and protective factors affecting sexual risk behavior among school-aged adolescents in Fiji, Kiribati, Samoa, and Vanuatu. AsiaPacific Journal of Public Health, 28(5), 404-415. https://doi.org/10.1177/1010539516650725

Poerwandari, E. (2007). Pendekatan kualitatif untuk penelitian perilaku manusia (Qualitative approach for research on human behavior). LPSP3 Fakultas Psikologi Universitas Indonesia.

Potard, C., Courtois, R., \& Rusch, E. (2008). The influence of peers on risky sexual behaviour during adolescence. The European Journal of Contraception \& Reproductive Health Care, 13(3), 264-270. https://doi.org/10.1080/13625180802273530

Santelli, J. S., Song, X., Holden, I. K., Wunder, K., Zhong, X., Wei, Y., ... Serwadda, D. M. (2015). Prevalence of sexual experience and initiation of sexual intercourse among adolescents, Rakai District, Uganda, 1994-2011. The Journal of Adolescent Health, 57(5), 496-505. https://doi.org/10.1016/j.jadohealth.2015.07.018

Sari, D. E., \& Rokhanawati, D. (2018). The correlation between age of first dating and sexual behavior of adolescents and young adults in Indonesia. Journal of Health Technology Assessment in Midwifery, 1(1), 23-28. https://doi.org/10.31101/jhtam.441

Shek, D. T. L., \& Leung, H. (2016). Do adolescent sexual behavior and intention to engage in sexual behavior change in high school years in Hong Kong? Journal of Pediatric 
and Adolescent Gynecology, 29(1), S49-S60.

https://doi.org/10.1016/j.jpag.2015.10.008

Sneed, C. D., Tan, H. P., \& Meyer, J. C. (2015). The influence of parental communication and perception of peers on adolescent sexual behavior. Journal of Health Communication, 20(8), 888-892. https://doi.org/10.1080/10810730.2015.1018584

Somers, C. L., \& Anagurthi, C. (2014). Parents ' attitudes about adolescents ' premarital sexual activity: The role of inter-parent consistency / inconsistency in sexual outcomes. Health Education Journal, 73(5), 545-553. https://doi.org/10.1177/0017896913506702

Steinberg, L. (2002). Adolescence. Mc. Graw Hill. Inc. Co.

Suleiman, A. B., \& Deardorff, J. (2015). Multiple dimensions of peer influence in adolescent romantic and sexual relationships: a descriptive, qualitative perspective. Archives of Sexual Behavior, 44(3), 765-775. http://doi.org/10.1007/s10508-0140394-Z

Sychareun, V., Phengsavanh, A., Hansana, V., Chaleunvong, K., Kounnavong, S., Sawhney, M., \& Durham, J. (2013). Predictors of premarital sexual activity among unmarried youth in Vientiane, Lao PDR: The role of parent-youth interactions and peer influence. Global Public Health, 8(8), 958-975. https://doi.org/10.1080/17441692.2013.830755

Temple, J. R., \& Choi, H. J. (2014). Longitudinal association between teen sexting and sexual behavior. Pediatrics, 134(5), 1-6. https://doi.org/10.1542/peds.2014-1974

Utami, E., \& Nodia, F. (2016, April 5). Angka kehamilan di kalangan remaja tinggi, BKKBN ubah strategi (Pregnancy rate among teenager is high, BKKBN change the strategy). Suara.Com. Retrieved from https://www.suara.com/lifestyle/2016/04/05/164816/angka-kehamilan-di-kalanganremaja-tinggi-bkkbn-ubah-strategi

Van de Bongardt, D., Reitz, E., Sandfort, T., \& Deković, M. (2015). A meta-analysis of the relations between three types of peer norms and adolescent sexual behavior. Personality and Social Psychology Review, 19(3), 203-234. https://doi.org/10.1177/1088868314544223

Wang, B., Stanton, B., Deveaux, L., Li, X., \& Lunn, S. (2015). Dynamic relationships between parental monitoring, peer risk involvement and sexual risk behavior among Bahamian Mid-Adolescents. International Perspectives on Sexual and Reproductive Health, 41(2), 89-98. https://doi.org/10.1363/4108915

Wanufika, I., Sumarni, S., \& Ismail, D. (2017). Komunikasi orang tua tentang seksualitas terhadap perilaku seksual pranikah pada remaja (Parental communication about sexuality on premarital sexual behaviorin adolescents). Berita Kedokteran Masyarakat, 33(10), 495-500. https://doi.org/10.22146/bkm.26079

Wong, L. P. (2012). Qualitative inquiry into premarital sexual behaviours and contraceptive use among multiethnic young women: implications for education and future research. PloS One, 7(12), e51745. https://doi.org/10.1371/journal.pone.005145

Ybarra, M. L., Strasburger, V. C., \& Mitchell, K. J. (2014). Sexual media exposure, sexual behavior, and sexual violence victimization in adolescence. Clinical Pediatrics, 53(13), 1239-1247. https://doi.org/10.1177/0009922814538700

Young, H., Burke, L., \& NicGabhainn, S. (2018). Sexual intercourse, age of initiation and contraception among adolescents in Ireland: Findings from the Health Behaviour in School-aged Children (HBSC) Ireland study. BMC Public Health, 18(1), 362. https://doi.org/10.1186/s12889-018-5217-z 